Mengenal Kebudayaan Keo:

Dongeng, Ritual dan Organisasi Sosial

P. Dr. Philipus Tule, SVD 


\title{
MENGENAL KEBUDAYAAN KEO: DONGENG, RITUAL DAN ORGANISASI SOSIAL
}

\author{
Oleh \\ P. Dr. Philipus Tule, SVD
}




\section{Mengenal Kebudayaan Keo: \\ Dongeng, Ritual dan Organisasi Sosial}

Penulis

ISBN

Layout @ Sampul

Foto Sampul
: P. Dr. Philipus Tule, SVD

: 978-602-60252-3-4

: Reginaldo Ch. Lake, ST, MT

: Dok. P. Dr. Philipus Tule, SVD

\section{Penerbit:}

\section{UNWIRA PRESS}

Universitas Katolik Widya Mandira

Jl. Jend. Ahmad Yani No. 50-52, Merdeka

Kecamatan Kota Lama, Kota Kupang,

Nusa Tenggara Timur, 85225

Telp. /Fax (0380) 833395 / 831194

e-mail: info@unwira.ac.id; www.unwira.ac.id

Dicetak oleh:

\section{APIX PRINTING}

Jl. Biak No. 3 Jakarta Pusat 10150

Telp. /Fax (021) 380 8038, 3859168 / 3806750

e-mail: apixprinting@gmail.com; www.apixprinting.com

Cetakan I, Maret 2019 Kupang: Penerbit UNWIRA PRESS, xii +120 ,

148 x $210 \mathrm{~mm}$

Hak cipta dilindungi oleh undang-undang.

Dilarang memperbanyak karya tulis ini dalam bentuk dan dengan cara apapun tanpa izin tertulis dari Penerbit UNWIRA PRESS 


\section{KATA PENGANTAR PENULIS DAN UCAPAN TERIMA KASIH}

Dalam bahasa Kéo, tak ada ungkapan khusus untuk 'terima kasih'. Namun demikian, hampir dalam semua pendarasan bhéa Kéo senantiasa menyebut nama orang (weta weki) dan mengingat namanya (sa ngara), baik orang hidup maupun yang telah meninggal, untuk segala pemberian material dan rohani yang telah diterima. Senada dengan bhea Keo, ada banyak individu dan institusi yang harus didaraskan bhea untuk mengungkapkan terima kasih. Hal itu tentu akan menjadikan halaman ini terlampau panjang. Maka secara selektif akan kusebut beberapa nama, yang mengungkapkan kesadaranku bahwa telah ada begitu banyak orang yang terlibat dalam merampungkan buku ini. Patut kusyukuri mereka semua.

Pertama, terima kasih untuk Pemerintah Daerah Kabupaten Nagekeo, khususnya Bupati Nagekeo Periode 2014 - 2018 (Drs. Elias Djo) dan Bupati Nagekeo Periode 2018 2024 (Dr. Johanes Don Bosco Do), Kepala Dinas Pendidikan dan Kebudayaan (Tarsisius Djogo, S. Sos) dan Kabid Kebudayaan (Wilibrodus Lasa, A.Md. Par) yang telah mempercayakan saya tugas menulis buku ini. Dukungan dana dan moril sungguh luar biasa untuk dapat merampungkan penelitian dan tulisan ini.

Kedua, terima kasih untuk Universitas Katolik Widya Mandira (Unika Widya Mandira) Kupang yang telah 
memberikan saya kesempatan melakukan penelitian ini dengan risiko beberapa kali harus meninggalkan tugas utama di kampus. Terima kasih juga kepada rekan dosen Didimus Dedi Dhosa, S. Fil, M.A yang menjadi mitra peneliti dan Reginaldo Ch. Lake, ST, MT sebagai editor, layout naskah dan designer cover buku ini; Sekretaris Kristina Yulita, SE dan Yohanes Rogan, S. Fil. Juga terima kasih untuk sekelompok mahasiswa dari etnis Keo yang belajar di Universitas Katolik Widya Mandira Kupang, antara lain: Aris Koa, Marselina Tin Meo, Petronela Bhudhe, Asri Bhala, Melania Gore, Oliver Siga, Risna Bhoko, Benediktus Kowa, Kapistrano Celina Ceme, Andreas Dako So'o, Muamar Sarifudin Serajawa, Mira Ema). Mereka telah bersedia terlibat dalam beberapa kali kegiatan Focus Group Discussion (FGD) di kampus dan kegiatan verifikasi di lapangan berhubungan dengan berbagai data dan cerita rakyat Keo di wilayah asal penuturnya masing-masing.

Ketiga, terima kasih untuk para informan kunci dan para pemuka adat di ketiga Kecamatan wilayah Keo (Mauponggo, Keo Tengah dan Nangaroro) yang telah meluangkan waktu untuk melakukan beberapa kali Focus Group Discussion (FGD) di pusat Kecamatan. Mereka itu adalah Mikhael Dhae, Arnold Dhae, Alfons Mere, Barnabas Kaka (Mauponggo), Blasius Minggu, Marsianus Bei, Yan Nanga, Ambrosius Fedha, Stanley Jawa, Benediktus Geju (Keo Tengah), dan Wilhelmus Masa, Paulus Pio, Thadeus Dhato, Yeremias Misi, Thomas Tiba Owa dan Yohanes Raja (Nangaroro). 


\section{SEKAPUR SIRIH \\ DRS. ELIAS DJO}

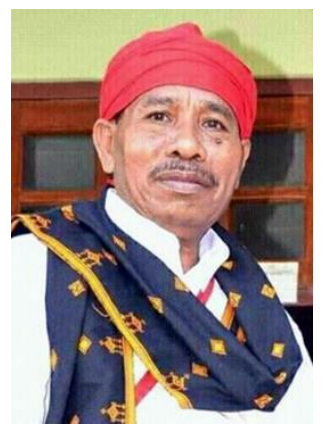

Puji dan Syukur kehadirat Tuhan Yang Maha Kuasa atas Berkat Rahmat dan KaruniaNya penulisan buku dengan judul: "Mengenal Kebudayaan Keo: Dongeng, Ritual dan Organisasi Sosial" dapat diselesaikan dengan baik dan tepat waktu. Menelusuri jejak sejarah asal usul nenek moyang suatu daerah yang telah berlalu ratusan bahkan ribuan tahun tentu bukanlah pekerjaan mudah, apalagi tidak didukung argumentasi yang lengkap baik lisan maupun tulisan yang secara rasional dapat diyakini keabsahannya.

Begitu keberadaannya ketika kita hendak menelusuri asalusul dan adat budaya masyarakat Keo. Sebagai generasi yang keberadaan etnisnya telah diakui sejak lama jauh sebelum adanya penataan batas-batas wilayah dan suku bangsa sampai Indonesia merdeka, agaknya suatu kewajiban yang tidak boleh diabaikan untuk terus aktif menggali dan menelusuri sejarah, adat istiadat baik dalam bentuk dongeng, ritual maupun organisasi sosial masyarakat yang ada sekarang.

Karenanya, apa yang dipaparkan dalam buku ini merupakan sebuah refleksi dari ungkapan adat masyarakat Keo "susu buku nama nete" yang artinya menggali dan menelusuri kembali tentang adat istiadat, dongeng, ritual dan organisasi sosial masyarakat. Ma'e ndu ne'e huku ma'e dangga ne'e ada merupakan ungkapan adat yang mengajak kita untuk tidak 
melupakan hukum adat yang berlaku di masyarakat berbudaya karena akulturasi tidak hanya terjadi pada makanan saja melainkan juga dalam keseharian kita. Mudah-mudahan paparan yang sederhana ini merupakan kontribusi pendapat untuk menjalin mata rantai sejarah perjalanan hidup dan mengenal adat istiadat Keo tersusun indah sebagai sesuatu yang berkesinambungan. Kami patut menyampaikan ucapan terima kasih yang berlimpah kepada Yang Terhormat Pater Dr. Philipus Tule, SVD dan Tim Peneliti yang telah menggali kembali adat istiadat dan budaya dalam sebuah Buku Budaya Keo.

Kepada semua pihak yang telah memberikan dorongan dan masukan kiranya dapat membawa manfaat bagi perkembangan adat dan budaya Nagekeo di masa yang akan datang. Kiranya Tuhan senantiasa memberkati kita. Terima kasih.

Bupati Nagekeo (periode 2013-2018) 


\section{SEKAPUR SIRIH BUPATI NAGEKEO}

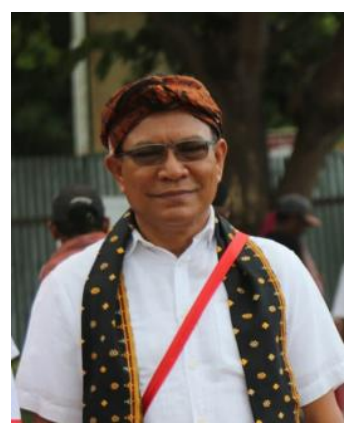

Saya sampaikan terima kasih dan penghargaan untuk P. Philipus Tule dan tim peneliti dari Universitas Katolik Widya Mandira (UNWIRA) Kupang dalam kerjasama dengan para tokoh masyarakat adat di wilayah Keo yang telah berhasil merampungkan buku berjudul Mengenal Kebudayaan Keo: Dongeng, Ritual dan Organisasi Sosial. Terima kasih juga kepada bapak Bupati Nagekeo, Drs. Elias Djo, Bupati pendahulu saya dan Dinas Pendidikan dan Kebudayaan Kabupaten Nagekeo yang telah berinisiatif mendukung program penelitian dan publikasi ini.

Penerbitan sebuah buku tentu menggambarkan visi dan misi perjuangan suatu warga masyarakat berbudaya literasi. Serentak pula hal itu menggambarkan perhatian dan kerinduan masyarakat untuk menggali dan mendokumentasi kekayaan budayanya sebagai inspirasi dalam kehidupan masa kini, tapi juga sebagai warisan nilai bagi generasi masa depan.

Beberapa pakar antropologi dan linguistik mancanegara telah meneliti dan mempublikasi tentang budaya dan masyarakat Nagekeo. Patut disebut nama Prof Gregory Forth, Prof Andrea Molnar, dan Dr Louise Baird. Rintisan penelitian dan publikasi mereka itu menyadarkan kita bahwa khasanah budaya Nagekeo itu bagaikan sumber air yang tak pernah kering dan selalu memuaskan dahaga para pencahari ilmu. Maka, tampilnya 
segelintir peneliti dan penulis pribumi seperti P. Philipus Tule, Cyrilus Bau Engo (alm), P. Charles Beraf menjadi fenomen bangkitnya pengemban budaya lokal yang peduli, kreatif dan produktif.

Sebagai pimpinan pemerintah daerah Nagekeo kami menyambut baik kegiatan literasi (penelitian dan publikasi) itu dengan merancang lagi suatu program pendukungnya berupa Festival Literasi Nagekeo 2019. Bertemakan "Melalui Perpustakaan Membangun Rumah Peradaban Baru di Timur Indonesia”, kami berikhtiar agar melalui perpustakaan dapat ditumbuh-kembangkan semangat literasi sehingga melahirkan peradaban baru di Nagekeo yakni peradaban masyarakat dengan semangat literasi (membaca dan menulis) Atas cara tertentu hal itu dapat mendorong pengembangan ekonomi kreatif mulai dari tingkat desa. Perlu kami informasikan bahwa saat ini di Kabupaten Nagekeo terdapat dua belas Taman Baca Masyarakat di tingkat desa dengan fokus untuk anak-anak sekolah dan juga untuk masyarakat Petani di desa.

Apa motivasi saya dan kawan-kawan menyelenggarakan kegiatan seperti itu? Tidak lain karena kami membaca fenomena kegelisahan kaum muda, generasi pelanjut, yang merasa kehilangan semangat dan minat meneliti, membaca dan menulis. Oleh karena itu, beberapa publikasi yang telah muncul sebelum Festival Literasi tahun 2019 ini akan menjadi instrumen cerahbudi (aufklarung), sekaligus menginspirasi generasi muda Nagekeo untuk lebih peduli mengumpulkan dan menulis tentang budaya sendiri. 
Generasi muda Nagekeo ke depan membutuhkan bahan bacaan sejarah dan budaya tertulis (literasi) yang perlahan-lahan tapi pasti terus menggeser budaya lisan (oral). Dengan demikian, terbuktilah kebenaran pepatah Latin: Verba vollant, littera scripta manet yang berarti kata-kata lisan akan terbang (menghilang), tapi kata tulisan akan tinggal (bertahan).

Dr. Johanes Don Bosco Do (Bupati Nagekeo Periode 2018 - 2024) 
Dipersembahkan bagi masyarakat Kabupaten Nagekeo yang merayakan

\section{Hari Ulang Tahun ke-12}

Kami Orang Keo. Kami Beriman dan Berbudaya

Gambar 1: Misa Syukur Imam Baru di Kampung Worowatu, 26 Sept. 1993

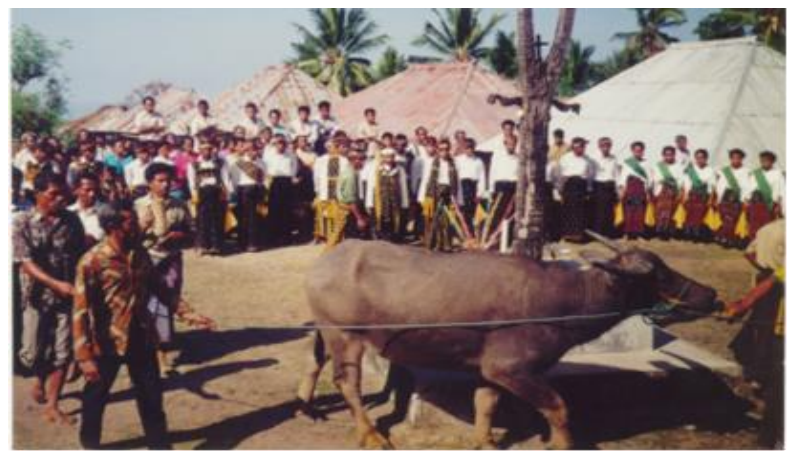

Gambar 2: Tokoh Masyarakat Adat di sekitar Monumen Budaya Peo di Kampung Adat Wajo, Keo Tengah

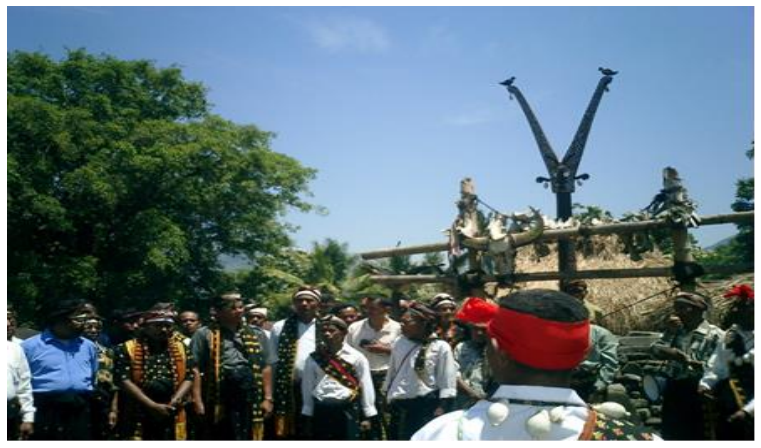




\section{DAFTAR ISI}

Kata Pengantar Penulis dan Ucapan Terima Kasih iii

Sekapur Sirih Drs. Elias Djo......................................................

Sekapur Sirih Bupati Nagekeo ..................................................vii

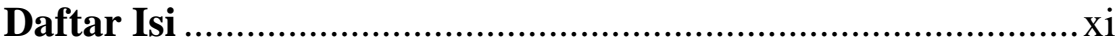

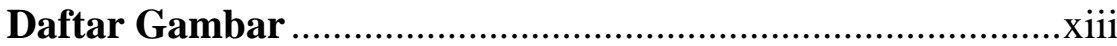

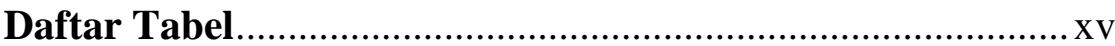

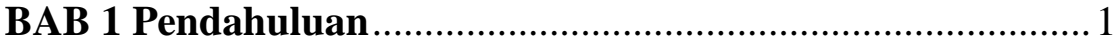

BAB 2 'Ata Kéo Dan Kawasan Pemukimannya ......................9

Riwayat Tanah Keo Masa Pra-Kolonial ........................................10

Keo: Beralih dari Kabupaten Ngada menjadi Kabupaten

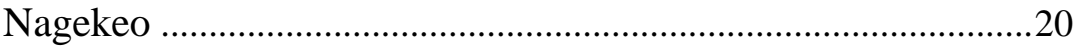

BAB 3 Relasi Manusia dan Tanah........................................22

Tata Kelola dan Relasi Dengan Tanah Ulayat .............................24

Tanah Sebagai Ibu .....................................................................

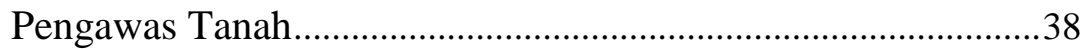


Orang Luar yang Diinkorporasi

BAB 4 Agama Dan Kepercayaan Orang Kéo ....................... 59

Relasi Orang Kéo Dengan Leluhur dan Yang Ilahi ............ 60

Agama Monoteis Memasuki Wilayah Kéo ........................... 81

BAB 5 Organisasi Sosial Berbasis Rumah ........................ 94

Rumah dan Peringkatnya ...................................................... 94

Tiang Rumah (Deke) dan Isu Presedensi ............................... 108

BAB 6 Rumah Sebagai Buku Dan Teater ........................ 121

Masyarakat Berbasis Rumah Menurut Lévi-Strauss ............... 122

Rumah Sebagai Buku dan Teater.......................................... 124

Rumah Kéo: Aspek Fisik dan Simbolik................................. 125

BAB 7 Dongeng Asal Usul Suku................................... 135

Empat Mitos Keo Dalam Perbandingan .............................. 136

BAB 8 Kesimpulan ................................................... 153

Apendix Dongeng...................................................... 161

Daftar Pustaka ............................................................. 199

Riwayat Hidup Penulis................................................ 207 


\section{DAFTAR GAMBAR}

Gambar 1: Misa Syukur Imam Baru di Kampung Worowatu .................................................... $\mathrm{X}$

Gambar 2: $\quad$ Tokoh Masyarakat Adat di sekitar Monumen Budaya Peo di Kampung Adat Wajo, Keo Tengah ........................................................ X

Gambar 3: Peta Afdeeling Flores, administrative division 1909-1929/2931 .............................................. 15

Gambar 4: Peta Afdeeling Flores dan pembagian wilayah administrarifnya 1929/1931-1950. Sesudah 1950 hanya batas-batas onderafdeeling dipertahankan. Distriknya kini disebut Kabupaten ...................................................... 17

Gambar 5: $\quad$ Peta Sepuluh Hamente Tana Kéo ..................... 18

Gambar 6: Bapak 'Ameka'e Wea,'ine tana 'ame watu dari Worowatu ...................................................... 39

Gambar 7: Kepala Babi untuk Orang Terhormat .............. 49

Gambar 8: Skema Struktur presedensi dalam tata kelola dan penggarapan tanah ulayat Kéo.................. 55

Gambar 9: Bapak Hubertus Bu'u mewakili 'Embu Mame sedang menikam babi dengan tombak (tumba) waktu upacara bangga di Nua Tudiwado, disaksikan oleh 'Ameka'e Muwa dan Moses Ndana........................................................... 75 
Gambar 10: Bapak Jamaludin Husein sedang menyembelih seekor ayam jantan. Darahnya diurapi pada barang pusaka suku sebelum ditempatkan dalam peti pusaka yang baru .................................... 80

Gambar 11: 'Ameka'e Muwa, pemimpin upacara sedang membaca hati ayam, meramalkan masa depan nиa (kampung) dan penduduknya .................. 80

Gambar 12: Skema Organisasi Kampung Worowatu dengan simbol keranjang ........................................... 98

Gambar 13: Keranjang (wati, gata dan mboda): simbol organisasi sosial.............................................. 101

Gambar 14: Organisasi Kampung 'Udi berdasarkan simbol keranjang 103

Gambar 15: Organisasi Sosial Kampung di Keo 109

Gambar 16: Tiang-tiang (deke) dari Sa'o Jara di kampung 'Udi yang menghadirkan keempat kelompok dalam kampung ........................................... 114

Gambar 17: Denah Rumah Kéo ....................................... 127

Gambar 18: Tampak Rumah Kéo dari Sisi Samping ....... 128

Gambar 19: Isometri Rumat Keo dari Sisi Vertikal ......... 131

Gambar 20: Isometri Rumat Keo dari Sisi Vertikal ......... 132

Gambar 20: Isometri Proses Membangun Rumat Keo..... 133 


\section{DAFTAR TABEL}

Tabel 1. Vokal pada Dialek Kéo Tengah dan Timur.............. 6

Tabel 2. Simbol Konsonan pada Dialek Kéo Tengah dan Timur .................................................................. 7

Tabel 3. Misi di Pulau Solor dan Flores pada abad ke-16 ... 83 



\section{BAB 1 \\ PENDAHULUAN}

Kéo di Kabupaten Nagekeo, di Flores Tengah menjadi fokus studi etnografis ini. Buku ini merupakan hasil penelitian yang intensif oleh seorang putera daerah Keo bersama timnya di kampung halaman sendiri. Hasil penelitian itu diperkaya dengan hasil Focus Group Discussion (FGD) yang dilakukan di tiga Kecamatan di wilayah Keo dan diperdalam bersama beberapa kelompok akademisi dalam beberapa seminar kebudayaan yang diselenggarakan oleh Dinas Pendidikan dan Kebudayaan serta Pariwisata Kabupaten Nagekeo sejak tahun 2017 dan 2018. Kami coba mengangkat dan membahas beberapa isu seputar organisasi masyarakat adat, mitos dan ritus serta praktik keagamaan dan budaya di tengah konteks masyarakat bangsa dan dunia yang terus ditandai oleh fenomena modernisasi dan perubahan.

Suatu pelajaran yang unik dari Kéo adalah bahwa kendati interaksi religius dan kultural membawa banyak perubahan dalam masyarakat, tapi tetap juga terwariskan sejumlah masalah. Masuknya Islam dan Kristen ke kawasan ini pada awal abad ke-16, dan lebih intensif pada awal abad ke-20, telah membawa perubahan mendasar di kalangan penduduk lokal dengan pertobatan menjadi penganut agamaagama monoteis, baik Katolik maupun Islam. Kendatipun mayoritas atau bahkan seluruhnya telah menganut agamaagama monoteis, mereka pun masih menghayati agama dan 
kebudayaan lokal sebagai bagian dari identitas atau jati diri mereka. Pandangan kosmologis mereka yang sangat menekankan harmoni dengan tanah dan arwah para leluhur, terejawantah lewat berbagai mitos (dongeng-dongeng), silsilah keturunan, berbagai ritus atau upacara yang dirayakan seputar monumen budaya dan rumah-rumah adat mereka. Semua hal itu lasimnya menjembatani jurang dan bahkan memperkecil potensi konflik antara para penganut agama-agama yang berbeda.

Kebanyakan umat beragama di Keo merasa bangga bahwa mereka memiliki kesatuan dan ikatan genealogi yang sama sebagai bagian dari identitas mereka. Genealogi itu secara pragmatis tercipta dan dilanggengkan di tengah masyarakat modern yang terus berkembang maju. Bagi masyarakat Keo, agama Islam dan agama Katolik tidak hanya merupakan agama wahyu yang terungkap dalam Kitab Suci, tapi juga menjadi basis dari apa yang mereka percaya dan lakukan serta hayati dalam konteks lokal.

Untuk lebih memahami lingkungan masyarakat dan budaya yang unik itu, kami akan membahas konsep orang Kéo tentang dongeng, ritual dan organisasi sosial masyarakat adatnya. Kendati pun nuansa masyarakat berbasis rumah sangat dominan di antara orang Keo, toh tetap ditemukan adanya variasi. Pelbagai variasi itu sungguh kaya dengan berbagai unit sosial yang terungkap dalam kontribusi atau sumbangan waktu ritual adat yang dikenal dengan nama ndou mapi. Sumbangan adat itu serentak menggambarkan stratifikasi sosial masyarakatnya dalam bentuk: keranjang 
kecil (wati), keranjang menengah (gata) dan keranjang besar (mboda). Realitas ini menggugat dan bahkan memodifikasi teori Lévi-Strauss, seorang pakar antropologi dari Perancis yang cenderung menggeneralisasi, menyamakan dan bahkan mereduksi semua istilah kekerabatan sosial ke dalam nuansa 'masyarakat berbasis rumah'.

Organisasi sosial masyarakat berbasis rumah dan unit sosial yang lebih kecil itu mengatur interaksi dan relasi antara masyarakat Keo dan menjelaskan unit-unit sosial, ekonomis, politis dan religiusnya. Karena itu, rumah dan unit-unit sosial di bawahnya tidak saja mengungkapkan relasi antara warga dan kerabatnya melalui perkawinan dan aksi saling memberi (seperti pemberian belis), tapi juga melalui relasi dengan arwah leluhur dan 'Yang Ilahi' melalui berbagai mitos, ritus dan korban.

Dalam hubungan dengan agama, orang Keo umumnya mengakui diri secara publik sebagai penganut agama Katolik atau Islam. Namun, jelas bahwa mayoritas penduduk Keo masih sungguh terlibat dengan kepercayaan setempat yang menjunjung tinggi penghargaan terhadap arwah leluhur yang terejawantah lewat berbagai rumah adat dan monumen budaya. Identitas yang kompleks inilah yang menginspirasi saya untuk meneliti dan menulis buku yang berjudul: MENGENAL KEBUDAYAAN KEO: DONGENG, RITUAL DAN ORGANISASI SOSIAL.

Bahan dasar untuk penulisan buku ini adalah hasil penelitian kami sejak tahun 1997, yang dilanjutkan dengan penelitian bersama beberapa rekan dan mahasiswa serta para 
pemuka adat Keo sejak tahun 2017. Sejak saat itu, kami senantiasa melakukan observasi dan Focus Group Discussion (FGD) serta seminar tentang berbagai hal seputar kebudayaan Keo, sambil menjalani tugas sebagai dosen dan Rektor Universitas Katolik Widya Mandira. Sambil menjalani tugas sebagai Rektor dan mengasuh Mata Kuliah Islamologi, Ilmu Perbandingan Agama dan Antropologi Budaya, saya pun tetap mencari kesempatan untuk menguji dan mengklarifikasi berbagai topik kajian, serta mengorganisir berbagai pertemuan antarumat beragama sebagai wahana dan kesempatan menerapkan berbagai ide dan hipotesis yang dikembangkan dalam perkuliahan dan forum akademik lainnya.

Aksi refleksi dan analisis serta revisi berkelanjutan tentang masyarakat dan budaya Keo dalam buku ini sesungguhnya merupakan hasil pergumulan pribadi dan perjumpaan dengan berbagai mitra diskusi dan pegawai Dinas Kebudayaan dan Pariwisata Kabupaten Nagekeo beberapa tahun terakhir. Mereka itu, khususnya Pemerintah Daerah Nagekeo terus mendorong dan mendukung secara moril dan finansial agar saya dapat menerapkan berbagai teori dan hipotesis dalam kehidupan yang nyata. Sebagaimana sering saya rujuk dari pernyataan Russell di berbagai kesempatan bahwa 'knowledge without love, and scholarship without personal involvement and commitment, are dead' // Ilmu Pengetahuan tanpa cinta, dan kepakaran tanpa keterlibatan dan komitmen personal adalah mati (Russell 1988: xi).

Dalam bagian pendahuluan ini, kami ingin memperkenalkan secara ringkas tentang bahasa Keo sebagai 
bahasa yang dipakai di kawasan tiga Kecamatan yang menjadi area penelitian ini. Juga dijelaskan mengenai tata cara penulisan (ortografi) dan pengejaannya. Bahasa yang digunakan oleh masyarakat Keo (Keo Barat, Keo Tengah dan Keo Timur) adalah serumpun dialek yang dikenal dengan bahasa Keo. Antara ketiga dialek tersebut terdapat perbedaan, apalagi bila dibandingkan dengan bahasa Nage. Dialek Keo Barat dipakai di Kecamatan Mauponggo atau Keo Barat (di Kelurahan Mauponggo, desa: Bela, Aewoe, Wolokisa, Wuliwalo, Maukeli, Lokalaba, Wolotelu, Jawapogo, Lajawajo, Ululoga, Lodaolo, Woloede, Wuewolo, Selalejo, Selalejo Timur, Ua, Kota Gana, Keliwatulewa, Sawu). Dialek Keo Tengah dipakai di Kecamatan Keo Tengah (di desa: 'Udi Worowatu, Mbae Nua Muri, Kéli, Lewa Ngera, Wajo, Pau Tola, Lado Lima, Koto Wuji Timur, Koto Wuji Barat, Witu Romba 'Ua, dan beberapa desa di Kecamatan Nangaroro seperti Koto Diru Mali, Riti and Tonggo). Sedangkan dialek Keo Timur dipakai di Kecamatan Nangaroro (di desa: Ute Dodo, Oda Ute, Nata Ute, Ute Toto, Woe Doa, Bi Doa, Ulu Pulu, Pago Mogo, Dena Doa, Woe Wutu, Woko Doko Roro, Woko Woe, Tonggo, Riti, Pode Nura, Dega Lea, Kota Keo, Kota Keo 1, Kota Keo 2).

Belum banyak publikasi tentang bahasa Keo, kecuali yang dibuat oleh Dr Louise Baird $(2002,2003)$ dan Philipus Tule (2003, 2004), serta Forth (1994a, 1994b, 1995). Tata penulisan atau ortografi yang dipergunakan dalam buku ini sesuai dengan yang dilakukan oleh Forth dan Baird. Namun, 
ada beberapa cara baru ketika saya menulis nama-nama tempat yang lebih disesuaikan dengan bahasa setempat.

Dalam Tabel 1 berikut, saya memperkenalkan bunyi vokal dari Keo Tengah dan Timur sebagaimana ditulis dalam kamus-kamus bahasa tua, misalnya mengkhususkan satu simbol fonetik untuk satu bunyi, yang disusul dengan satu deskripsi teknis, huruf grapheme yang dipakai untuk menulisnya dengan cara penulisan (ortografi) yang praktis disertai contoh-contohnya.

Tabel 1. Vokal pada Dialek Kéo Tengah dan Timur

\begin{tabular}{|c|l|c|l|}
\hline$/ \mathrm{a} /$ & Seperti $\boldsymbol{a}$ dalam bapa & a & kamba $=$ kerbau \\
\hline$/ \mathrm{i} /$ & Seperti $\boldsymbol{i}$ dalam 'bibit' & $\mathrm{i}$ & kima $=$ siput \\
\hline$/ \mathrm{u} /$ & Seperti $u$ dalam 'buku' & $\mathrm{u}$ & tubu $=$ tunggul \\
\hline$/ \leftrightarrow /$ & Seperti e dalam 'tendang' & e & kepa $=$ nyamuk \\
\hline$/ \mathrm{e} /$ & Seperti $\boldsymbol{e}$ dalam 'kereta' & é & kéke $=$ sisir \\
\hline$/ \mathrm{o} /$ & Seperti $\boldsymbol{o}$ dalam 'lorong' & o & mboda $=$ keranjang \\
\hline
\end{tabular}

Sistem pengejaan dalam bahasa Keo yang dipakai dalam buku ini didasarkan pada tata penulisan (ortografi) bahasa Indonesia dan hampir semua simbol diucapkan dengan cara yang sama seperti dalam bahasa Indonesia. Sedangkan dalam Tabel 2, saya menyajikan suatu deskripsi untuk 8 (delapan) cara penulisan simbol konsonan yang dipakai dalam bahasa Kéo yang berbeda dengan ortografi bahasa Indonesia. 


\section{Tabel 2. Simbol Konsonan pada Dialek Kéo Tengah dan Timur}

\begin{tabular}{|c|l|c|l|}
\hline $\begin{array}{c}\text { Simbol } \\
\text { fonetik }\end{array}$ & \multicolumn{1}{|c|}{ Deskripsi bunyi } & $\begin{array}{c}\text { Pengejaan } \\
\text { Keo }\end{array}$ & \multicolumn{1}{|c|}{ Contoh } \\
\hline$/ ? \mathrm{~b} /$ & $\begin{array}{l}\text { Tak ada bunyi ini dalam bahasa } \\
\text { asing lainnya, kecuali beberapa } \\
\text { dialek serumpun yang ada di } \\
\text { sekitar. }\end{array}$ & $\boldsymbol{b h}$ & $\begin{array}{l}\text { bhéa }=\text { darasan } \\
\text { kisah diri dan } \\
\text { suku }\end{array}$ \\
\hline$/ \mathrm{mb} /$ & $\begin{array}{l}\text { Seperti bunyi mb pada kata } \\
\text { 'ember }\end{array}$ & $\boldsymbol{m b}$ & mbani $=$ berani \\
\hline$/ ? \mathrm{~d} /$ & $\begin{array}{l}\text { Tak ada bunyi ini dalam bahasa } \\
\text { asing lain, kecuali dalam } \\
\text { beberapa dialek di sekitar. }\end{array}$ & $\boldsymbol{d h}$ & dhoka $=$ tuli \\
\hline$/ \mathrm{nd} /$ & $\begin{array}{l}\text { Seperti bunyi nd pada kata } \\
\text { Indonesia }\end{array}$ & $\boldsymbol{n d}$ & ndia $=$ disini \\
\hline$/ \mathrm{N} /$ & $\begin{array}{l}\text { Bunyi velar seperti bynyi } \boldsymbol{n g} \text { pada } \\
\text { kata mengosongkan. }\end{array}$ & $\boldsymbol{n g}$ & $\begin{array}{l}\text { ngaki }= \\
\text { membersihkan }\end{array}$ \\
\hline$/ \mathrm{N} \gamma /$ & $\begin{array}{l}\text { Sama dengan bunyi } \text { ngg pada kata } \\
\text { 'menggoreng' }\end{array}$ & $\boldsymbol{n g g}$ & monggo $=$ bundar \\
\hline$/ \mathrm{x} /$ & $\begin{array}{l}\text { Tak ada bunyi ini dalam bahasa } \\
\text { asing lain, kecuali pada beberapa } \\
\text { dialek di sekitar. }\end{array}$ & $\boldsymbol{g h}$ & ghawo $=$ rajin \\
\hline$/ ? /$ & $\begin{array}{l}\text { Bunyi glottal stop seperti bunyi } \\
\text { Alif dalam bahasa Arab. }\end{array}$ & ' & $\begin{array}{l}\text { 'imu }=\text { dia; } \\
\text { 'embu }=\text { kakek } \\
\text { nenek/leluhur/ } \\
\text { ma'u= pantai }\end{array}$ \\
\hline
\end{tabular}

Dalam seluruh buku, semua kata bahasa daerah akan ditulis dalam huruf miring (italic) di dalam kurung seperti (kamba). Kata bahasa asing (Belanda, Inggeris dan bahasa lain) akan ditulis dalam bentuk huruf miring tebal dan di dalam kurung seperti (onderafdeelingen). Demikian pula nama-nama tumbuhan dalam bahasa Latin yang diambil dari Verheijen (1990) akan ditulis dalam huruf miring dalam kurung seperti (Cassia fistula). 


\section{APENDIX DONGENG}

\section{Dongeng Tonga Gadis dari So'a}

Dahulu ada Embu Nderu. Dia pergi ke pasar di So'a. Pulang pasar, di pinggir jalan dia mendengar tangisan bayi di tali kada yang sebesar paha. Lalu dia membelah tali kada itu. Dia melihat bayi putri kecil yang kemerahmerahan. Anak itu tidak besar, sama besarnya dengan jari kelingking saja.

Sesudah itu, dia pulang ke rumah dengan bayi itu. Dia berpikir:" Saya memberi makanan apa untuk bayi ini?" Di sana ada danau (Dana So'a) dengan pandan laut. Dia mengambil buah pandan laut yang sudah masak. Dia isap, isap dan menyuapi bayi itu. Bijinya dia kumpulkan dalam karung. Sudah agak lama karung itu penuh, dan dia mengisi lagi dalam sebuah karung lain. Sudah dua

\section{Nu Nange Embu Tonga Mbu'e So'a (Dialek Keo Tengah)}

Pu'u do'e-do'e datu 'Embu Ndéru.Kai mbana pasa réde So'a. Wado pasa, 'ena singi rada 'imu déde 'éa a 'ena tadi kada ma sama pa'a. Négha ke 'imu wegha tadi kada nde. 'Imu téi 'ana tolo loa, ta fai. Jadi 'ana nde nggedhe mére, sama kanga 'éko wi'e.

Négha ke wado née 'ana nde 'ena sa'o. 'Imu piki, nga'o piara pagha wai 'apa 'ana te. 'Ena ke ma né'e nanga (Nanga So'a) née peja ma'u.'Imu wiki peja ma'u ta té'a.'Imu 'eso 'eso 'eso (bhiso bhiso) woti 'ana. Ta di'e 'imu dhindu 'one depo. Ooo negha monggo ébho, depo nde oo mbenu 'imu pusi wadi ha depo ta pésa. Depo négha di'e rua. 
karung.

Dia menaruh bayi itu dalam kotak yang dibuat dari labu. Dia menamakan anak itu Tonga. Waktu anak itu sudah besar, sudah gadis, dia berkata: "Nenek, nenek, mari kita pergi ke pantai". Mereka berdua langsung turun. Lalu mereka tiba di Seko Nangge dekat Ma'umbawa, di atas Ae Tolo. Mereka singgah di tempat Paja Wae. Tanah di atas tepi sungai, tanah itu dimiliki Kakek Paja Wae. Lalu mereka tinggal bersama Kakek Paja Wae. Tidak diketahui apakah mereka memiliki hubungan keluarga atau tidak.

Setelah beberapa hari Mbu'e Tonga melihat sebatang pohon di Ma'undai. Dia berkata kepada Kakek Paja Wae: "Kakek, kakek. Di sana itu pohon apa? Daunnya tidak ada. Saya mau mencoba pergi."

"Baik", jawab Kakek Paja Wae.

Lalu Mbu'e Soa langsung pergi dengan karung pandan

'Ana go'o nde 'imu pusi 'ena bhu tora.'Ana nde 'imu séu ngara 'imu Tonga. Napa 'ana nde négha mére, négha mbu'e wadu, 'imu si'i: 'embu 'embu ee...ndua kita dau ma'u'. 'Imu ko'o rua nde simba ndua. Négha ke 'imu dhu rade Séko Nangge, wée Ma'u Mbawa, wawo 'Ae Tolo.'Imu ko'o tudi rade Paja née Wae. Tana wawo mbaka dowo ke tana ko'o 'embu Paja Wae. Négha ke 'imu ko'o mera née 'embu Paja Wae. Kita mona mbéo 'imu ko'o nde datu hubu famili oo nggedhe.

Négha ke poa rua oo tedu, Mbu'e Tonga nde téi sai ko'o do kaju ha pu'u mena Ma'undai. 'Imu sodho $k a$ 'embu Paja Wae: "embuembu. Nore na kaju 'apa na? Wunu ki 'iwa. Ja'o rapa mbana'.

Modo, dhewo 'embu Paja Wae.

Négha ke Mbu'e So'a simba mbana née depo di'e 
lautnya itu. Dia berjalan dari Ma'umbawa ke timur, sambil menanam di mana-mana benih pandan laut itu. Tiba di Ma'undai, dia melihat sebatang pohon tanpa nama di tengah kampung Ma'undai sekarang ini. Itu alasan kita mempunyai monumen budaya di tengah kampung Ma'undai dengan batu itu.

Waktu itu ada seorang pemuda namanya Taku Nuru yang turun dari Wodo Watu. Mereka bertemu dan saling berkenalan. Dia langsung menikah dengan Taku Nuru, penatua Worowatu. Mereka memiliki tiga orang anak: Waja De'e, Waja Ake dan Waja Sebho.

Pohon itu tanpa nama, kita tidak tahu pasti pohon apa. Pohon itu tidak punya daun. Pohon tanapa nama itu jatuh dengan ujungnya ke arah Pulau Jawa. Karena itu, orang Jawa menjadi kaya.

Maka dia menetap di Ma'undai. Lalu mereka naik ke Tudiwado; dengan реја та'u 'imu nde. 'Imu mbana pau pu'u rade Mbawa nuka mena, na toni, na toni pau ko'o peja mau nde. Sa'i ka dau Ma'undai, 'imu téi pu'u kaju ngara nggedhe, 'ena ora nua Ma'undai nambu te. Ma simba tau tubu nusu ora nata ne'e watu ma nde.

Nambu nde, 'ana suko ha ngga'e ngara Taku Nuru ndua pu'u Worowatu.'Imu ko'o papa luka née simba papa mbéo. 'Imu simba aki né'e Taku Nuru, mosa daki Worowatu, né'e dhadhi ana ngga'e tedu: Waja Dé'e, Waja 'Ake né'e Waja Sébho.

Pu'u kaju ngara mona nde kita mona mbé'o ko'o kaju 'apa. Kaju nde wunu mogha mona. Kaju ngara nde mona mboka 'udu ndia, bhodo mboka 'udu dau Jawa. Simba tau bhanda pau 'ata Jawa.

Simba 'imu mera pau dau Ma'undai. Negha ke 'imu ko'o nuka Tudi Wado; simba né'e 
monumen Ia dan Nambe di sana. Worowatu itu kemudian, ketika leluhur kita mengungsi ketika terjadi tsunami berhubungan dengan kasus Mbu`e Wondo.

\section{Dongeng Gadis Dewata}

Pada awal mula hiduplah di Pautola seorang kakek bernama Ndona Wea. Orang meremehkan dia. Orang menganggap remeh karena dia tak mampu untuk mengadakan pesta korban. Dalam perjamuan bersama, orang selalu menghidangkan untuknya nasi yang kebanyakan kacang dan daging yang kebanyakan tulang. Namun dia menerima dan mengumpulkannya. Karena merasa malu, dia lalu membentangkan tikar besar di halaman serta mengundang segenap masyarakat di kampung itu, untuk mengadakan pamitan. Dalam pamitan itu dia berkata: "Pandanglah pemberianmu ini (saya kembalikan padamu)". Lalu dia berangkat, bersama 'ia nambe ma rade ke Worowatu ke wa'o muri, napa sira palu séra (mesi nuka) nambu mesi nuka née Mbu'e Wondo.

\section{Nu Nange Bu'e Nitu (Dialek Keo Barat)}

Pu'u lo'e-lo'e pu'u mena Pautola muri 'ebu Ndona Wéa. Ata wéke re'e kema koka ne'e 'imu. Pandi wéke re'e kema koka, 'uru 'imu ta paya talo wela talo.'Ata siba ti'i 'imu 'etu séwe yobho, pora sewe toko.'Imu dhindu. Negha ke 'imu rasa mea 'imu siba weka te'e mere 'ena wewa léwa, 'imu 'enga rebu manusia 'ena tuka nua tola 'ola. 'Imu siba seru: 'miu 'ono sai ko'o miu menga ke'. Negha ke 'imu siba kai sama sama ne'e weta 'imu a ga'e. 
seorang saudarinya.

Dia bergerak menuju tebing Wolo Pau. Dia berhenti di sana. Karena dia masih bisa melihat kampungnya, maka ia meneruskan perjalanannya. Dia berhenti lagi di Nda'a $\mathrm{Au}$ (dekat Ngera di tepian sebelah barat). Ia memasang kupingnya dan masih didengarnya kokokan ayam di kampung Pau. Lalu dia terus bergerak turun menuju Guyu Pie. Dia tinggal di Guyu Pie, namun dia merasa tak aman karena deburan ombak. Dia lalu berangkat lagi menuju wolo Ngodho.

Ketika menjelang pesta korban dia merencanakan perjalanannya ke Ine Rie. Namun dia ditahan oleh seorang kakek bernama Ndona Ngodho untuk menetap di sana. Seusai pesta adat tersebut dia diberikan sebidang tanah untukdigarap. Di samping menggarap tanah, ia juga menyadap tuak di lereng Wolo Wea.

Keesokan hari, ada dua orang gadis datang meminta
'Imu la'a nuka réle lebi wolo pau. 'Imu reke 'ena ke. 'Imu toru dhatu tei nua; negha ke 'imu la'a tero.'Imu reke napa rale Nda'a 'Au. 'Imu ito, manu kako dhatu lele. 'Imu la'a kai nuka lau Guyu Pie ('Au Pile). 'Imu ndi'i lau Guyu Pie. 'Imu lele bata uu paa, 'imu kai rale wolo Ngodho.
Negha ke we'e mo'o pebha 'imu mo'o kai nuka rale' Ine Rie, bholo meka Ndona Wéa si'i reke 'ena te. So pebha negha siba ti'i ne'e ku yema tau kema. Imu siba kara ne'e tua rele lebi Wolo Wéa. 
tuak. Dia memberikan mereka tuak dalam bambu berukuran besar. Namun kedua gadis itu tak mau menerimanya karena terlalu sedikit. Sesudah itu, Ndona Wea berkata: "Sebaiknya kamu mencari sendiri alat pengisi tuak." Keduanya langsung mengambil dan memotong sejenis aur yang berukuran kecil. Baru beberapa tetes tuak diisi dalam bambu itu kelihatannya sudah penuh. Keduanya berkata: "Aduh, sangat berat." Keduanya berjalan sambil terus menerus beristirahat.

Sesudah itu setiap pagi kedua gadis itu datang terus meminta tuak, namun tak diberikan lagi oleh Ndona Wea. Karena tidak diberikan, maka kedua gadis itu mengambilnya tanpa pemberitahuan. Karena itu, setiap pagi didapatinya bambu tampung tuaknya kosong.

Setelah itu, ebu Ndona Wea mengawasi siapakah yang mengambil tuaknya. Pada suatu waktu, dia tua. 'Imu ti'i tua wai léko, bholo sira wina ga'e bhia. Négha ke meka Ndona Wéa si'i: 'miu gae dhato (ko'o 'ola pusi)'. Negha ke ga'e rua nde siba kiru wai ko'o guyu nitu, mewi ka a ndeti rua négha benu. 'Imu ko'o si'i: eee ndate. 'Imu rua nde bana 'ena mera, 'ena mera.

Négha ke oo ge poa ge poa ngénde meka Ndona Wéa mona ti'i. Oo mona ti'i gae rua wenga beki ngata. $O$ wenga beki, 'ebu Ndona Wéao se'a bonga kena, o sé'a bonga kena.
Négha ke 'imu ('ebu Ndona Wéa) nepi, sai ta wenga tua imu. Nabu a déka 'imu sa'i si ga'e rua nabu 
mendapati kedua gadis itu sedang mencuri tuak. Yang seorang (yang kakak) sedang berada di puncak pohon tuak, yang seorang (yang adik) lainnya ada di tanah. Sang gadis yang di tanah ketika melihat Ndona Wea datang lansung di melarikan diri. Sedangkan yang di atas pohon tuak ketika turun langsung ditangkap. Dia dipegang erat-erat.

Ketika ditangkap, perempuan itu menjelma menjadi ular, halipan (kaki seribu), ular lainnya. Sedangkan yang paling akhir adalah seekor tabuan. Dia langsung menggenggamnya erat-erat. Dia mengosongkan kapur dalam tabung bulu (pengisi kapur) dan mengisinya dengan tabuan tersebut. Tabung itu disumbat dan diberinya lubang kecil agar tabuan tersebut tidak mati.

Setibanya di kampung ia mengisi tabuan tersebut ke dalam sebuah keranjang penyimpan benang.

Setiap hari ia pergi ke kebun untuk mengolah tanah. wenga. Ha ga'e reta tolo tua, a ga'e rale tana. Ta rale tana so tei 'ebu Ndona Wea tadho siba payu. Ta reta tolo tua o dhodho ke, so dhu rale tana 'ebu Ndona Wea siba pojo. Imu pojo nemo.
Ha pojo siba bale ko'o nipa, ko yeti 'api, ko'o iku. Bholo 'imu mona welu. Wa'o épo siba bale ko'o fua kondo. So, bale fua kondo, 'imu siba kepo nemo. O kepo nemo, 'imu dhega néa ko'o 'oka 'ila 'imu. Siba pusi ko'o fua kondo rale 'one 'oka. Suki nemo née lia a so'o dhéko suki 'imu, taku mata. Nuka réle nua 'imu tugi 'ena ko'o gopu lélu (sondu lélu). 
Ketika dia kembali dari kebun ke rumah, makan telah tersedia. Setiap hari terjadi yang sama. Dia lalu bertanya kepada tetangga: "Siapakah yang ada di rumah?" "Apa sebabnya," tanya para tetangga. "Ketika saya kembali dari kebun, makanan selalu tersedia," jawabnya. Para tetangga menjawa: "Tidak, kami tak melihat seorang pun. Kami hanya melihat asap yang mengepul. Kami mengira bahwa kamu yang memasang api." "Tidak, tidak. Bukan aku," jawab Ndona Wea. "Saya ada di kebun." Setelah itu, dia memata-matai untuk mencari tahu siapakah sesungguhnya melakukan semuanya itu.

Pada suatu siang, ketika suasana sepi, dia bergegas masuk ke rumah melewati balok di tengah balai-balai rumanya. Dia berjalan berjingkrak-jingkrak ke dalam rumah dan langsung membuka pintu dengan cepat. Ndona Wea melihat seorang gadis sedang duduk tepekur di atas dapun sambil menenun. Gadis itu terkejut, sa'o'étu boto négha, pora boto négha. Ge lera ge lera dhatu sama wi'e. 'Imu so nuka 'étu boto négha, pora boto négha. Négha ke 'imu 'ale $\mathrm{ka}$ 'ata ta sa'o wée: 'Né'e sai ndia sa'o?' 'Ta 'ila ba gha', 'ata ta sa'o wée 'ale. 'O nga'o walo pu'u 'ena 'uma, 'étu boto négha, pora boto négha', 'imu dhewo. 'Ata sa'o wé'e dhewa: 'mona, kami mona téi sai. Kami tuga téi 'api ta nu. Kami ye kau'. 'Mona ga, nga'o mona', 'ebu Ndona Wéa dhewo. 'Nga'o 'ena 'uma'. $O$ négha 'imu siba nepi ka. To'o poa 'imu nepi.

Ne'e kisa lera, péro iwu i ka (peta leta), 'imu siba nai dhéko lata ora.'Imu nai dhihadhiha siba kai wesa nde. 'Ebu Ndona Wéa téi 'imu teku mengu pau 'ena wawo lapu. Siba ita ('ata fai nde). 'Kau bai omi', bu'e Nitu si'i. Nga'o senda la'e tiko lio nua, kau cu ka. Ke mona 'apa', bu'e Nitu si'i. Meka Ndona Wéa nde siba fai. Bholo gere fai imu 


langsung menangis dan
berkata: "Engkau terlalu paya.
cepat. Saya belum
menyelesaikan tenunanku
untuk mengitari seluruh
kampung. Engkau terlalu
cepat," kata Bu'e Nitu.
"Namun begitu, tak apa-
apa," katanya. Ndona Wea
berencana untuk menikahi-
nya. Namun sebelum
menikahinya, dia harus
menyelenggarakan upacara
korban.

Dalam mempersiapkan diri untuk pesta korban itu, dia mengerjakan kebun yang ditanaminya dengan pelbagai jenis tanaman namun hanya labu yang tumbuh. Setelah labu dibelahnya baru kelihatan padi. Padi itu disimpannya dalam keranjang yang bukan dibuat dari lontar, tetapi dari kulit kayu.

Setelah cukup banyak padi tertampung, Bu'e Nitu menyuruh Ndona Wea meminjam kerbau merah, babi merah dan kambing merah. Tetapi Ndona Wea menjawab: "Saya tak sanggup meminjam."

Négha ke 'imu kema 'uma.'Imu kema 'uma, 'one 'uma tuga tebu mége ko'o kula. So'o pi'a kula téi wai pae. 'Imu ngana ipe mére, mona wai koli bholo wai ko'o u'i kaju.

Négha ke 'imu si'i 'ebu Ndona Wéa: 'Kau sogo kaba toyo, wawi toyo, yongo toyo'. 'Nga'o sogo talo', 'ebu Ndona Wéa si'i. 'Mona kau la'a lo'. 'Nga'o talo, nga'o talo', 'ebu Ndona Wéa si'i. 'Kau la'a lo'. Talo ka 'imu, 'ebu Ndona Wéa 
"Pergilah saja," Bu'e Nitu mendesak. Dalam keadaan terpaksa, Ndona Wea pergi meminjam. Beberapa hari kemudain, Bu'e Nitu menanyakan: "Apakah kerbau merah, babi merah dan kambing merah sudah semuanya siap?" Jawabnya: 'Ya."

Setelah itu, Bu'e Nitu pergi meminta babi besar pada saudara-saudaranya di gua Uwi-iwa. Saudaranya langsung menghantar, namun dalam rupa babi hutan di bawah kolong rumah. Sedangkan saudaranya dalam rupa ular besar yang bertengger di ujung balaibalai (tenda). Anjing yang disembelih untuk saudaranya berupa tikus. Belis yang diberikan dalam bentuk daun lontar yang diukir dan diwarnai dengan kunyit dan kabur sebagai pengganti emas.

Sesudah itu, Bu'e Nitu berkata: "Undanglah masyarakat seluruhnya. Kita mau berpesta". Dia membunyikan gong. Manusia berdatangan. Setelah itu ia mengambil siba kai la'a sogo. Négha ke, 'ebu Nitu 'ale ka yaki 'imu: 'Kaba toyo, wawi toyo, yongo toyo nde noto ka?' 'Imu dhéwo: 'Noto ka'.
Négha ke, Bu'e Nitu kai la'a ngénde wawi mére 'ena 'ame naya 'imu 'ena lia 'Uwi'iwa (Lia Goka/Lia Nitu). Naya 'imu siba 'endi, bholo téi wai wawi yui rale 'au lewu. Née naya 'imu téi wai goka mére 'ena sepu téda. Négha poga lako tau ti'i 'ame naya 'imu, wai ko'o dhéke. Tau fau ngawu wai ko'o wunu koli teri née kune 'oka; tau né'e ritu giu 'imu pawe-pawe tau nia wéa loda. 
kain tenunan Bu'e Nitu (kain suta) dibentangnya dari dalam rumah hingga di halaman. Bu'e Nitu bertanya: "Sudah sampai ke tanah?" "Ya", jawabnya. Sementara gong gendang dibunyikan Bu'e Nitu turun dari dalam rumah ke halaman sambil menari. Pada saat itu segenap khalayak ramai menyaksikan Bu'e Nitu menari. Mereka begitu bersemangat menontonnya, sampai ada yg memanjat pohon kelapa untuk melihatnya dengan lebih jelas.

Setelah pesta usai, keduanya hidup sebagai suami istri yang sah dan melahirkan 7 (tujuh) orang anak, yang terdiri dari 5 putra dan 2 putri. Kelima orang putra itu adalah: Lena Seko, Tae Seko, Raga Seko, Meo Seko dan Bele Seko. Kedua putri adalah Lengga Seko dan Lejo Seko.

Suatu hal yang aneh terjadi pada diri anak yang pertama. Jikalau ada dorang yang ingin menggendongnya, ia menjelma menjadi seekor ular hijau. Jikalau dilepas-
'Wéka dhu ka rale tana?', Bu'e Nitu 'ale.'Dhu ka', imu si'i. Paka ka go, tera ka laba. 'Ebu Nitu siba poro pu'u réta 'one sa'o siba fai aki biasa dhadhi 'ana ga'e lima rua nde. nuka rale tana; siba a iwu téi ka; nai jeka tolo nio mo'o moni 'imu nde. 
kan, ia menjelma kembali menjadi manusia biasa. Sang putri Lengga Seko, pada saat menonton pesta di Ngera, dia bertanding dengan seorang lelaki penabung gendang, dengan perjanjian: "Bila saya kalah dalam tarian, maka saya akan tetap tinggal di sini (Ngera) dan menjaid istrimu. Tetapi bila saya menang, maka saya akan kembali ke kampung halamanku. Dalam pelaksanaannya, ternyata nona Lengga kalah. Dia akhirnya tinggal dan menjadi istri sang penabuh gendang, di rumah Piru Pola. Kemudian dihantarlah belis ke Paulundu.

Lama kelamaan, sebagai suami dan istri, Ndona Wea dan Bu'e Nitu terlibat dalam pertengkaran. Karena itu Ndona Wea menampar Bu'e Nitu. Bu'e Nitu lalu pergi menyingkir ke pinggir kali dan menghilang tanpa jejak. moni mena Ngera de ta pébha paya, 'imu papa taji ngata née 'ata mena.'Ngara ata Ngera tera laba talo nga'o walo', 'imu si'i. 'Bholo ngara nga'o talo, ke nga'o siba mera ndia'. Tau-tau paka go laba nde, 'ebu Lengga bebi tau-tau 'ebu Lengga talo. Napa negha lera léwa, tau-tau 'ebu Lengga siba tau fai 'ata ta tera laba nde, 'one sa'o ko'o Piru Pola.So wa'o muri siba 'endi ngawu nuka rale Paulundu.
Mera-mera 'ebu Ndona Wéa ne'e 'ebu Nitu 'imu rua fai aki papa boyo. Ko'o ngewa tau, 'ebu Ndona Wéa siba wasa ne'e lima fai 'imu nde. Négha ke 'ebu Nitu siba kai nuka rili singi 'ae. So dhu rili singi 'ae siba pota. 


\section{Dongeng Gadis di Pucuk Kelapa}

Dahulu ada seorang lakilaki dan seorang perempuan yang tinggal di Kedi Watu Wea. Mereka berdua suamiisteri. Perempuan itu melahirkan tujuh anak. Nama dua anak laki-laki Niko dan Nima.Anak yang kedua dari bungsu bernama Mona. Nama anak-anak lain tidak diketahui. Anak bungsi bernama Mbu'e Dombo Nio, karena dia lahir dalam bentuk kelapa. Saudarasaudaranya, melihat ibu mereka melahirkan sebuah kelapa, mereka mencungkil dan menendangnya. Seorang saudaranya, yang bernama Mona, mengambil dan melindungi kelapa itu. Dia berkata:" Jangan! Walaupun dia sebagai kelapa, dia pun berasal dari perut ibu juga. Dia bukan sembarang kelapa yang tiba-tiba muncul".

Lalu dia menyimpan kelapa itu di sudut dekat dapur dan menutupinya. Setiap hari dia memeriksa sudut itu, di mana kelapa

\section{Nu Nange Mbu'e Dombo Nio}

\section{(Dialek Keo Tengah)}

Datu pu'u nembu réde Kédi Watu Wéa muri 'ata fai née 'ata aki ha ngga'e. 'Imu rua fai ki. Ta fai nde dhadhi 'ana ngga'e dima rua. Ta nala (ta aki) ngara 'imu Niko, Nima. Ta ka'e ko'o 'ana sepu susu ngara 'imu Mona. Ta pésa-pésa nga'o ghéwo. Ta sepu susu ngara 'imu Mbu'e Dombo Nio, 'uru 'imu dhadhi 'one rupa ko'o nio. Ta nala 'imu ngga'e dima, 'uru téi 'ine 'imu ko'o dhadhi wai nio, 'imu koo' séti senda. Née ta nala 'imu ta ha ngga'e ta ngara Mona 'imu sepo ngepo nio nde. 'Imu si'i: 'ma'e, 'éde ko'o nio, 'imu nggedho pu'u tuka ko'o 'ine mogha. Mesi ko'o nio ta mé'a démba'. 
diletakkan.

Kemudian

muncul tunasnya kelapa itu.

Mona memberitahukan mamanya: "Mama, mama, adik tersenyum kepada saya." Padahal kelapa yang bertunas itu. Mamanya berkata: "Ya, jagalah baikbaik adikmu." Mona berkata: "Mereka itu (saudarasaudaranya) jangan menggendong adikku".

Walaupun tunas kelapa itu bertumbuh semakin tinggi, kelima saudara tidak peduli. Waktu tunas kelapa itu sudah tinggi, Mona pergi menanamnya. Dia membuat pagar sekitarnya. Pagar itu disusun dari tumpukan batu sekitarnya. $\mathrm{Di}$ atasnya dibuatnya tutupan, agar tidak dikenai sinar matahari. Kehidupan kelapa itu bertumbuh siang dan malam. Subur. Ketika pohon kelapa sudah tinggi di puncaknya muncul seorang gadis yang cantik sekali. Kelima saudara itu tidak percaya. Hanya Mona yang selalu membersihkan dan memperhatikan adiknya di atas bhusu né'e tembu. Mona nde sodho $\mathrm{ka}$ 'ine 'imu: 'ine 'ine eee...., 'ari ma tawa pau né'e nga'o'. 'Imu mona mbé'o ke ko'o nio ta tembu nde. 'Ine 'imu si'i: 'modo, tau ri'a-ri'a née 'ari kau'. Mona si'i: 'ongga peka ke (ka'e-ka'e 'imu) ma'e ka'o ghako 'ari nga'o'.

Tau tau jeka nio nde tembu déwa, sira ta ngga'e dima nde mona ie. Tembu nio nde négha déwa, Mona nde kai mbana toni. 'Imu tau né'e kopo. Kopo tule né'e kota gidi géo. Réta wawo 'imu tau née tutu, mo'o dera ma'e nggena. Nio nde muri nuwa kombe dera. Subur. Nio négha déwa, réta dombo nio suda née 'ata fai mbu'e ta gaga lai. 'Imu ko'o ta ngga'e dima mona percaya. Tungga Mona ta selalu pui susi, reko pengo pau 'ari imu réta Dombo Nio. 
pucuk kelapa.

Tidak lama kemudian orang Jawa yang berlayar dengan perahu di laut, melihat gadis itu di atas pucuk kelapa. Orang Jawa itu merapat ke pantai di pantai Mburu, di muara yang beranama Nanga Wawi. Nama Nanga Wawi itu berasal dari air babi yang tumpah waktu mereka mengantar gadis itu. Orang Jawa itu mendaki ke Gunung Watu Wea. Orang bertanya kepada mereka: "Maksud apa kalian datang ke sini?"

"Kami mencari seorang perempuan," mereka menjawab. Kelima saudara itu berkata: "Kami di sini tidak ada perempuan".

Orang Jawa itu menjawab: "Tidak. Kalian di sini mempunyai perempuan yang cantik sekali”.

Mereka mengumpulkan semua gadis di kampung itu. Mereka menunjukkan gadis seorang demi seorang kepada orang Jawa itu. "Yang ini, bukan?" mereka bertanya.
Mera-mera, 'ata Jawa ta mbana née sope (lajo) dau 'ae mesi, imu ko'o téi mbu'e nde réta Dombo Nio. 'Ata Jawa nde simba tobhe né'e sope dau Mburu, dau nanga ngara 'imu Nanga Wawi. Ngara Nanga Wawi ke pu'u 'ae wawi ta roe nambu 'imu ko'o tu peja mbu'e nde. 'Ata Jawa nde nuka réde Kédi Watu Wéa. 'Ata ade 'imu ko'o: 'miu tau 'apa nuka ndia?'

'Kami mo'o nggae 'ata fai', 'imu ko'o dhewo. Sira ta ngga'e dima nde sodho: 'kami ndia 'ata mbu'e mona datu'.

'Ata Jawa nde dhewo: 'Mona. Miu ndia née 'ata fai ta modhe roe'.

'Imu ko'o tiwo ka 'ata (ta mbu'e) 'one nua nde.'Imu ko'o péla ha ngga'e ha ngga'e 'ena 'ata Jawa nde. 'Ke оoо? іти ko'o 'ade. 
"Tidak," orang Jawa berkata.

"Yang ini bukan?"

"Tidak."

"Yang ini, bukan?"

"Tidak."

Setelah beberapa orang ditunjukkan tetapi mereka selalu berkata "tidak".

"Kalian coba tunjukkan yang mana," kata mereka.

Orang banyak itu menatap, dan melihat seorang gadis. Kelima saudara itu memanggilnya tetapi tanpa sahutan. Mona sendiri (saudara termuda) akhirnya memanggil saudarinya itu: "Turunlah, saya juga setuju." Mendengar saudaranya Mona memanggilnya dia (Mbu'e Dombo Nio) langsung turun. Orang Jawa berkata: "Yang itu, betul".

Mereka langsung mengantar gadis itu ke pantai dengan daging babi yang telah dimasak dan babi yang hidup. Tetapi orang Jawa itu berkata: "Haram untuk
'Mona', 'ata Jawa sodho.

Ke ooo?

Mona.

Ke oоo?

Mona. Ngga'e wutu dima, bhodo 'imu ko'o sodho mona penga.

'Ata Jawa nde si'i: 'Ma ne'e. Ma réta Dombo Nio kéra'.

Sira ta woso nde 'ono, téi 'ata fai ha ngga'e. Sira ta woso ngga'e dima bhodo niuniu. Napa Mona (ta aki ta so'o 'ari) dhato né'e wuku ka weta 'imu nde: 'dhodho sai, nga'o mogha setuju'. Déde nala 'imu Mona nde niu, 'imu (mbu'e Dombo Nio) simba dhodho. 'Ata Jawa nde sodho: 'ma ke, tu'u mbé'e'.

Sira nde simba tu peja ndua dau ma'u née 'étu wawi mboto, née wawi ta muri. Bhodo sira 'ata Jawa nde sodho: 'kami ta pile' ['imu ko'o 'ata 'Islamu?]. 'Ae wawi 
kami." Daging babi dan sayurnya itu dibuang di situ, dan langsung menjadi Nanga Wawi. Babi yang hidup itu dilepaskan dan langsung menjadi Watu Wawi di dekat Mburu Mere.

Kemudian Mbu'e Dombo Nio berbicara dengan saudaranya Mona: "Baiklah. Karena engkau sudah setuju baiklah. Hanya engkau harus selalu memperhatikan tempatku itu. Kalau engkau melihat pucuk kelapa itu layu, itu pertana saya sudah mati. Engkau harus mengambil pulang tulang belulangku".

Setiap hari Mona selalu memperhatikan pucuk kelapa itu. Sudah agak lama dia melihat pucuk kelapa itu sudah layu. Melihat pucuk kelapa itu layu dia langsung berangkat dengan sebuah blek berisi kapas menuju tanah Jawa Goa.

Waktu sudah tiba ternyata saudarinya memang telah meninggal. Suaminya menyiksa dengan menyiangi kebun karena mereka telah ta mboto nde simba bhobhe dhoa 'ena ke, simba jadi pau Nanga Wawi. Wawi ta muri nde simba dela dhoa, ne'e simba jadi pau Watu Wawi dau we'e Mburu Mere ke.

Négha ke Mbu'e Dombo Nio nde punu ka né'e nala 'imu Mona: 'Modo. Bhida kau négha fonga ke modo ka. Tungga kau 'ono ii 'ena da'e dondo nga'o ke. Ngara kau téi dombo nio ke médu, ke nga'o mata ka. Kau ngési mada wado toko mbuku nga'o'.

Nggé nggé dera, Mona nde guda ii 'ena Dombo Nio.Monggo ébho, 'imu téi dombo nio nde médu ka. Téi dombo nio nde médu, 'imu simba kaki né'e bele ha di'e, né'e foro dédu pusi 'ena bele kai ndua dau tana Jawa Goa.

Négha dau, daka weta 'imu négha mata ka tu'u mbée. Ta aki 'imu huku kema tau mbene 'uru 'imu ko'o négha dhadhi né'e 'ana. Pu'u 
memiliki anak. Padahal dia hanya terbiasa me-mintal benang dan menenun. "Karena kita sudah mempunyai anak engkau menyuruh saya bekerja di kebun. Baiklah," Mbu'e Dombo Nio berkata kepada suaminya. Dia langsung membersihkan rumput di kebun mereka sebanyak tujuh petak. Dia membersihkan rumput dari atas ke bawah. Turun dari petak teratas sampai petak di pinggi bawah. Dia bekerja petak demi petak. Setelah menyelesaikan satu petak telapak kakinya luka. Begitu dia menyelesaikan tujuh petak, mencapapi pinggir kebun terbawah dia meninggal. Hanya lemaknya tersebar di setiap petak. Tulang belulangnya terdapat di pinggir kebun terbawah, di petak terakhir.

Saudaranya datang, dan mencelupkan kapas ke dalam lemaknya. Tiba di pinggir kebun terbawah dia mengumpulkan tulang belulang dan mengisinya ke dalam blek. Membawanya pulang ke Gunung Watu Wea. Dia du dera, 'imu tungga biasa tau kingge né'e senda dédu.'Uru kita dhadhi ka née 'ana, kau si'i nga'o ngema 'uma lema. Ke modo', mbu'e Dombo Nio punu né'e aki 'imu.'Imu simba ngema ka 'uma 'imu ko'o ape dima rua. Bhodo 'imu ngema 'uma nde pu'u réde ra'i.'Imu ngema ndua. Ndua pu'u réde ra'i jeka ridi luli. 'Imu ngema ape ha ape. Mbeja ha ape tuka a'i 'imu neka. Ngema rembu ape dima rua, oo ridi luli 'imu simba mata. Tungga ta mina 'imu ke nama ape todo wésa léla. Ta toko mbuku 'imu napa ridi luli, ridi ape sepu.
Ta nala nde démba, 'imu reto ka ta mina nde née foro dédu. Dhu ridi luli, 'imu simba sopi née ta toko pusi wado 'ena bele. Mendi wado nuka réde Kédi Watu Wéa. 'Imu bhobhe wado 'one dia wée pu'u nio ta mo'o mata nde. Nio 
menuang kembali ke dalam lubang dekat pohon kelapa yang hampir mati itu. Kelapa itu hidup kembali. Dia menyiram dengan air. Tidak lama kemudian kelapa itu hijau kembali. Gadis itu muncul kembali di atas pucuk kelapa itu. Oleh karena itu, berkembang biak lagi manusia di gunung itu.

Apakah gadis itu lalu bersuamikan Eko Witu atau melahirkan Eko Witu, tidak diketahui. Hanya orang bercerita bahwa Eko Witu itu sejak dilahirkan sudah memiliki gigi emas yang lengkap. Oleh karena itu, orang menamakan gunung itu Gunung Watu Wea (Gunung Batu Emas).

\section{Dongeng Anak Babi Merah}

Dahulu kala Embu Rangga Jani memiliki beberapa ekor kerbau di Ae Tolo Riti.Waktu dia jalanjalan menggembalakan kerbaunya, dia melihat di dalam kolam air seekor anak babi merah. Dia berkata: "Hei, nde muri wado.'Imu léki née 'ae. Mera mera nio nde meta wado. Jadi wado ka kita 'ata suda pu'u réta dombo nio. Simba mbi mbeka wado pau kita 'ata réde Kédi nde.

Mbu'e nde ta aki ne'e 'Eko Witu nde oo, ta dhadhi pau 'Eko Witu ('ana ko'o Dombo Nio) nde oo, nga'o mona mbéo. Tungga 'ata sodho bahwa 'Eko Witu nde pu'u dhadhi née ngi'i wéa mbenu mumu. Simba 'ata ma séu pau Kédi réde nde né'e ngara Kédi Watu Wéa.

\section{Nu Nange Wawi Tolo (Dialek Keo Timur/Riti/ Nangaroro)}

Pu'u nembu, 'embu Rangga Jani nde née kamba 'éko rua tedu ridi 'ae Tolo.Nambu 'imu mbanambana tito ko'o kamba 'imu, 'imu téi réde 'one 'ae 'ana wawi Tolo.'Imu si'i: 'Oe wawi 
babi milik siapakah itu? Barangkali babi orang yang jatuh.” Dia langsung mengambil bagi itu untuk dipeliharanya. Dia tidak punya istri. Dia membawa babi itu ke rumahnya. Dia kembali menggembalakan kerbau di padang yang kecil itu.

Dia mengikat babi itu di sudut dapur. Dia menyiapkan mmembuat bubur untuk makanan anak babi. Setiap hari terjadi begitu terus.

Dia tetap pergi menggembalakan kerbau ke padang itu. Ketika dia pulang rumah dia melihat sayursayuran dan makanan sudah dimasak. Dia berpikir: "Siapakah yang menyiapkan makanan ini? Saya telah menutup pintu dan jendela kuat-kuat dengan pasak. Biar untuk keluar saya pun melewati kolong. Saya cemas orang akan mencuri emas dan perak saya”.

Setiap hari terjadi begitu, makanan selalu tersedia. Dia memata-matainya.

Dia pulang ke rumah, waktu ko'o sai te o. Mbéghu wawi 'ata ta mesu pa 'ai'.'Imu simba wiki tau podu pagha ko'o 'imu. 'Imu ta fai nggedhe. 'Imu mendi 'ana wawi nde nuka réde sa'o. 'Imu mbana ru wado kamba dau mabha nde ma ha go'o.

'Imu 'ike wawi nde 'one 'oki dapu. 'Imu tau ka, raka né'e 'ae tau ka wawi 'ana. Nggé dera ma bhida ke pa.

Négha ke 'imu dhatu mbana tito kamba ndua ridi. $O$ 'imu wado sa'o, 'imu téi ko'o 'uta ka pesa negha mboto. Négha ke 'imu piki: 'sai ta tau ka te? Ko'o pate pene ja'o 'usu negi.'Ede ko'o nggedho ja'o wa'o 'au dewu. Taku 'ata naka ko'o wéa donda ja'o'. 
tengah hari.Dia memasuki rumahnya lewat kolong.Setibanya di dalam dia memandang dan melihat seorang gadis yang cantik sekali.Dia memasak untuknya.Dia berjalan berjingkat ke sudut dapur.Dia melihat kulit yang ditanggalkan anak babi itu tertumpuk di sudut dapur.Dia mengambil kulit yang ditanggalkan itu. Gadis itu memasak seperti biasa. Namun gadis itu bi su saja. Dia memanggilnya, menyapanya, tetapi gadis itu membisu seperti tunggul pohon.

Mereka di Riti bermusyawarah sebagai berikut: "Rangga, engkau pergi menggembalakan kerbau ke bawah. Sesudah itu enkgau membunuh seekor babi atau menikam seekor kerbau, yang darahnya kau gosokkan pada badanmu. Sesudah itu kita akan merapat. "Rangga melakukan begitu.

Mendengar ratapan itu orang di kampung bertanya: "Hei kalian meratapi apa?"

"Rangga mati." petu kée.'Imu nai dhéko dewu. Nuka réta 'imu 'ila, 'imu téi 'ata fai ha ngga'e ta gaga rata pau. Nasu 'uta tau ka ti'i 'imu.'Imu kada nuka 'ena 'onggi dolo. 'Imu téi ko'o 'uwa du ko'o 'ana wawi nde ma dudhu pau 'ena 'onggi dolo. 'Imu wiki uwa du nde.'Ine nde ma nasu pau 'uta bhida biasa. Tapi mbu'e nde jadi ngongo bhodo.'Imu niu, 'ade 'ona bhodo 'ine nde ngongo bhida tubu kaju.
Sira réde Riti musyawara bhida te: 'Rangga, kau tito kamba déo ridi. Négha ke kau keda wawi ha 'éko, o sengga kamba ha 'éko, ta la kau koma 'ena weki kau. Négha ke kita lita nangi'. Rangga kema bhida ke. 
"Mengapa?"

"Seekor

kerbau
'Uru 'apa?'.

'Oooo kamba wéti 'imu'.
Orang Riti ramai-ramai datang berkumpul, mereka memikul Rangga ke kampung. Tetapi karena Rangga meninggal karena ditanduk kerbau, maka dia tidak boleh dimasukkan ke dalam rumah dan ke dalam kampung, haram. Orang langsung memikul Rangga dan meletakkannya di atas batu di ujung atas kampung, yang langsung diberi nama "Watu Rio Rangga" (yang berarti "Batu tempat Rangga Dimandikan").

Dinda, nama gadis itu langsung terjun turun meratapi suaminya. Dia langsung berbicara seperti biasa. Orang Riti lalu memandikan Rangga di atas batu itu. Dinda langsung berbicara seperti manusia normal.

Mereka berdua lalu menikah dan melahirkan tujuh orang anak, dalam bentuk anak-anak babi. Ada tujuh ekor anak babi. Rangga
'Ata Riti nde todo poro kepu; bhéi ka Rangga nde nuka réde nua. Bhodo 'uru 'imu (Rangga) mata kamba wéti, maka 'imu mona ngada maso 'one sa'o né'e 'one nua (= pile). 'Ata simba bhéi né'e wedu 'imu 'ena todo watu réde 'udu пиа (simba séu Watu Rio Rangga). 
berkata: "Dinda, mari kita pergi mandi di laut, mencari siput dan ikan. Kita kumpul kan siput-siput kecil di pantai."

Rangga turun sambil membawa anak-anaknya dalam tujuh keranjang yang dibuat dari daun kelapa. Mereka mandi di laut di Ma`u Liti. Setelah mandi mereka pulang ke kampung Riti.Namun salah satu anaknya dilupakan di pantai. Anak babi yang betina. Orang Pulo (Pulau Ende) yang berlayar dengan sampan mendengar anak babi berteriak. Mereka langsung mengambilnya dan memuatnya dalam perahu menuju Pulau Ende.Rangga turun kembali ke pantai, tetapi anak itu sudah tidak terlihat lagi.

Mereka berdua dalam perjalanan pulang, seekor hilang lagi di kampung Nura dan menjadi batu. Batu itu besar sekali dan mempunyai susu. Sisa lima ekor ketika mereka tiba di kampung Ritu. Mereka menjadi 'ae mesi, tau kima 'ika kita. Poi léwo kita kewa dau mesi'.

Rangga nde ndua simba dhoi né'e 'ana-'ana 'imu nde wai kara kata 'esa dima rua. Rio 'ae mesi dau Ma'u Liti.Rio ho négha, 'imu ko'o wado nuka réde nua Riti.Bhodo 'ana 'imu ha ngga'e (ha 'éko) ghéwo dau mata ma'u.'Ana wawi ta moka.'Ata Pulo née sapa 'ambo déde 'ana wawi fi. 'Imu ko'o dhato né'e simba téi 'ana ta fai ha ngga'e. 'Imu ko'o simba wiki, wua née sapa 'imu ko'o ndua dau Pulo. 'Imu ndua wado dau mata ma'u, bhodo 'ana nde négha mona téi. 
manusia. Tetapi hingga dima nde. Bhodo 'ata sodho, sekarang kita tidak 'ana 'embu Wawi Toro (ta mengetahui persis keturunan mbade kita 'ata nde) mbi kelima orang itu. Tetapi ndada nuka 'emba-'emba: orang berkata bahwa Timor, Ende, Lio, ne'e keturunan Wawi Tolo Maumere. Nuka dawa rade tersebar ke suluruh penjuru: so'o liwu.

Timor, Ende, Lio dan Maumere. Ke barat lebih banyak. 


\section{DAFTAR PUSTAKA}

Adam, Jack, et al.,

1997 Baktiku Untuk Nusa Tenggara Timur. Yayasan

Citra Insan Pembaharu, Kupang.

Arndt, Paul, SVD

1951 Religion auf Ostflores, Adonare und Solor.

Studia Instituti Anthropos, Wien-Mödling.

1954 Gesellschaftliche Verhältnisse der Ngadha.

Studia Instituti Anthropos (8), Friburg.

Baird, Louise

2002 A Grammar of Keo: An Austronesian Language

of East Nusa Tenggara (PhD Thesis di The

Australian National University, Canberra).

Baird, Louise dan Philippus Tule, SVD

2003 Cerita Rakyat Keo (dalam Bahasa Keo,

Indonesia, Inggris). Ende: Penerbit Nusa Indah.

Barnes, R.H.

1974 Kedang: A Study of the Collective Thought of an Eastern Indonesian People. Clarendon Press, Oxford.

Biermann, Benno, M. O.P

1924 Die alte Dominikanermission auf den Solorinseln. Zeitschrift fur Missionswissenschaft 14:12-48.

Bourdieu, Pierre

1977 Outline of A Theory of Practice. Cambridge University Press, Cambridge.

1990 The Logic of Practice. Polity Press, Cambridge. BPS, Ngada

2006 Ngada Dalam Angka 2006. Central Bureau of Statistics, Bajawa. 
Clamagirand, B.

1975 La Maison Ende (Timor Portugais). Asie du Sud-est Monde Insulindien 6:35-60.

1980 The Social Organization of the Ema of Timor. In the Flow of Life: Essays on Eastern Indonesia, edited by James J. Fox, pp. 134-151. Harvard University Press, Cambridge.

Couvreur, A.

1924 Memorie van overgave van den aftredenden Resident van Timor en Onderhoorigheden. Algemeen Rijksarchief, Manuscript.

Cunningham, Clark, E.

1964 Order in Atoni House. Bijdragen tot de Taal-, Land- en Volkenkunde 120:34-68.

Dhakidae, Daniel (ed.). 2013. Soekarno: Membongkar SisiSisi Hidup Putra Sang Fajar. Jakarta: Penerbit Buku Kompas.

------. 2007.“Tantangan Ekonomi Politik Kabupaten

Nagekeo", dalam Philipus Tule dan Theofilus

Woghe (ed), Rancang Bangun Nagekeo.

Maumere: Ledalero.

Dietrich, Stefan

1989 Kolonialismus Und Mission Auf Flores (ca.1900-1942). Klaus Renner Verlag, Hohenschaftlarn.

1956 Nuer Religion. Clarendon Press, Oxford.

Djawanai, Stephanus

1983 Ngadha Text Tradition: The Collective Mind of the Ngadha People, Flores. Department of Linguistics, RSPAS, The Australian National University, Canberra

Evans-Pritchard, E.E.

1956 Nuer Religion. Clarendon Press, Oxford. 
Firth, Raymond

1969 Essays on social organisation and values. The Fontijne, L. Athlone Press, University of London, London.

1940 Grondvoogden in Kelimado. (unpublished, Koninklijk Instituut voor Taal-, Land- en Volkenkunde), Kupang.

1996 Guardians of the land in Kelimado. Manuscript, translated by Forth, G.

Frazer, J.

1890/1963 The Golden Bough: A study in Comparative Religion. Macmillan, London.

Forth, Gregory

1981 Rindi: An Ethnographic Study of a Traditional Domain in Eastern Sumba. Martinus Nijhoff, The Hague.

1991a Space and Place in Eastern Indonesia. Paper presented at CSEAS, University of Kent (Occasional Paper 9), Canterbury.

1994b Consideration of Kéo as an Ethnographic Category.

Oceania 64 (4): 302-315.

1998 Beneath the Volcano: Religion, Cosmology and Spirit Classifications Among the Nage of Eastern Indonesia. KITLV, Leiden.

1995 Two Terminologies from Eastern Kéo. Sociologus 45 (2): 153-168.

1996 Blood, sacrifice and efficacy among the Nage of central Flores. In For the sake of our future; Sacrificing in eastern Indonesia, edited by $\mathrm{S}$. Howell, pp. 73-91. CNWS, Leiden. 
1998 Beneath The Volcano: Religion, Cosmology and Spirit Classifications Among the Nage of Eastern Indonesia. KITLV, Leiden.

2001 Dualism and hierarchy: processes of binary combination in Kéo society. Oxford University Press, Oxford.

Fox, James, J.

1993 Memories of Ridge-poles and Cross-beams: The Categorical Foundation of a Rotinese Cultural Design. In Inside Austronesian Houses, edited by James Fox, J., pp. 141-179. Department of Anthropology, RSPAS, ANU, Canberra.

1995 Installing the Outsider Inside: The Exploration of an Epistemic Austronesian Cultural Theme and its Social Significance. Leiden University.

1996a The Transformation of Progenitor Lines of Origin: Patterns of Precedence in Eastern Indonesia. In Origins, Ancestry and Alliance: Explorations in Austronesian Ethnography, edited by James J. Fox and Clifford Sather, pp. 130-153. Department of Anthropology, RSPAS, The Australian National University, Canberra.

1997 The Poetic Power of Place: Comparative Perspectives on Austronesian Ideas of Locality, edited by James J. Fox. Department of Anthropology, RSPAS, The Australian National University, Canberra.

1999 Precedence in Practice Among the Atoni Pah Meto of Timor. In Structuralism's Transformations: Order and Revision in Indonesian and Malaysian Societies, edited by 
Lorraine V. Aragon and Susan D. Russell, pp. 3-36. Program for Southeast Asian Studies, Arizona State University, Arizona.

1996b The Paradox of Powerlessness: Timor in

Historical Perspective. Paper presented at The Nobel Peace Prize Symposium: Focus on East Timor, University of Oslo, December, 9.

Hamilton, H.A.L.

1918 Inleiding van een verslag over het landschap Kéo. Algemeen Rijksarchief, The Hague.

Heuven, B.H.F.van

1916 Nota Betreffende de Onderafdeeling Ngada (Manuscript).

Hooker, M.B.

1978 Adat Law in Modern Indonesia. Oxford Hocart, A.M.

University Press, Kuala Lumpur.

1936 Kings and Councillors. The University of Chicago Press, Chicago.

1952 The Life Giving Myth. Harper \& Row Publishers, Inc.,

1954 Social Origins. C.A. Watts \& Co Ltd, London. Howell, Signe

1996b A Life for Life: Blood and Other LifePromoting Substances in Northern Lio Moral Discourse. In For the Sake of our Future: Sacrifice in Eastern Indonesia, edited by S. Howell, pp. 92-109. Research School CNWS, Leiden.

Izikowitz, Karl Gustav, and Per Sørensen

1982 The House in East and Southeast Asia: anthropological and architectural aspects.

Curzon Press, London. 
Kohl, Karl-Heinz.

1998. Der Tod der Reisjungfrau: Mythen, Kulte und Allianzen in einer ostindonesischen Lokalkultur. Koln: W.Kohlhammer GmbH.

------ 2009. Raran Tonu Wujo: Aspek-Aspek Inti Sebuah Budaya Lokal di Flores Timur. Ledalero: Penerbit Ledalero.

Lévi-Strauss, C.

1983 The Way of the Masks. The University of Washington Press, London.

1987 Anthropology and Myth: Lectures 1951-1982. Basil Blackwell, New York.

Maier E. G. Th.

1917 Mailrapport No.2688/15 (Letter to the Governor General of the Netherland Indies in Buitenzorg, from the Commissioner of Timor and Dependencies, dated 7th May 1917). National Archives, Jakarta.

McKinnon, John, and Bhruksasri Wanat

1983 Highlanders of Thailand. Oxford University Press, Kuala Lumpur; New York.

Molnar, Katalin, A.

2000 Grandchildren of the Ga'e Ancestors: Social Organization and Cosmology among the Hoga Sara of Flores. Verhandelingen van het Koninklijk Instituut voor Taal-, Land-en Volkenkunde Press, Leiden.

Nakagawa, S. and Aoki, E.

1993 Endenese-English Dictionary (manuscript) Nordholt, Schulte, H.G.

1971 The Political System of the Atoni of Timor. Martinus Nijhoff, The Hague. 
Pigafetta, A.

1969 Magellan's Voyage. Yale University Press, New Haven.

Rawls,

1971 A Theory of Justice. Bellknap Press, Cambridge, MA.

Russell, J. Burton

1988 The Prince of Darkness: radical evil and the power of good in history. Cornell University Press, New York.

Robertson-Smith, W.

1889/1956 Lectures on the religion of the Semites.

The Meridian Books, New York.

Rockhill, W.W.

1915 Notes on relations and trade of China with the

Eastern Archipelago and the coasts of the Indian Ocean during the Fourthteenth Century. T'oung Pao 16.

Suchtelen, Jhr.B.C.C, M.M., van

1921 Endeh (Flores). Mededeelingen van Het Bureau

Voor De Bestuurszaken der Buitengewesten, Therik, Tom, G.

Bewerkt Door Het Encyclopaedisch Bureau 26.

1995 Wehali: The Four Corner Land, The

Cosmology and Traditions of a Timorese Ritual

Centre. PhD Thesis, The Australian National

University, Canberra.

Traube, Elizabeth, G.

1986 Cosmology and social life: ritual exchange among the Mambai of East Timor. University of Chicago Press, Chicago. 
Tule, Philippus, SVD

1998a The Indigenous Muslim Minority Group in

Ma'undai (Kéo) of Central Flores. Antropologi

Indonesia XXII (56):68-85.

1998b House-posts and the Baskets: Social

Organisation of 'Udi Worowatu People, Eastern

Kéo of Central Flores. Antropologi Indonesia XXII (57):110-118.

2003 Cerita Rakyat Keo. Ende: Penerbit Nusa Indah.

2004 Longing for the House of God, Dwellin in the House of the Ancestors: Local Belief,

Christianity and Islam Among the Keo of Central Flores. Fribourg/ Zwitzerland: Academic Press.

Verheijen, Jilis, J.A., SVD

1990 Dictionary of Plants Names in the Lesser Sunda Islands. Department of Linguistics, RSPAS, The Australian National University, Canberra.

Vischer, Michael, P.

1992 Children of the Black Patola Stone: Origin Structures in a Domain on Palu'e Island (Eastern Indonesia). $\mathrm{PhD}$ Thesis, The Australian National University, Canberra.

Weber, $\mathrm{M}$.

1890 Ethnographische Notizen uber Flores und Celebes. Internationales Archiv fur Ethnographie III (Supplement).

Waterson, Roxana

1991 The Living House: An Anthropology of Architecture in South-East Asia. Oxford University Press, Singapore. 


\section{RIWAYAT HIDUP PENULIS}

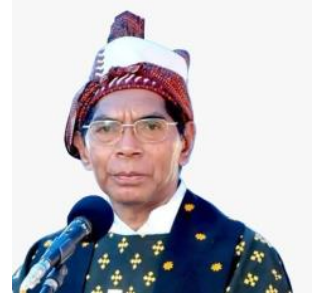

Philipus Tule lahir pada tgl 23 Maret 1953 di Kolinggi, Desa Udiworowatu, Kecamatan Keo Tengah, Kab. Nagekeo. Setelah tamat SDK Niodede (1966), SMPK Setia Budi Maunori (1969), melanjutkan pendidikan di Seminari Menengah St Pius XII Kisol, Manggarai Timur (1971), Seminari Menengah Todabelu-Mataloko, Ngada (1974). Tahun 1975 masuk Novisiat SVD di Ledalero dan studi di STFK Ledalero hingga tamat tahun 1983. Ditahbiskan imam pada 14 Juni 1984 dan bertugas setahun di Novisiat SVD Ledalero. Lalu melanjutkan studi Islamologi di Pontifical Institute of Arabic and Islamic Studies (PISAI) di Roma, Italia tahun 1985. Tahun 1987 mendalami bahasa Arab di Institut Oriental Dominican di Jln Masnah al-Tarabis Cairo sambil melakukan riset tentang karya Prof Ali Abd al-Raziq tentang "Islam Din La Dawlah" dibawah bimbingan Prof. George Anawati, OP. Kembali ke PISAI Roma dan selesaikan studinya dengan gelar Licentiat (Master) thn 1988. Thn 1995 melanjutkan studi di the Australian National University, Canberra, Australia. hingga tamat tahun 2001 dengan gelar $\mathrm{PhD}$ dalam Ilmu Antropologi. Beberapa publikasinya a.1 Mengenal dan Mencintai Muslim dan Mulsimat (2003, 2008), Allah Akbar Allah Akrab (2003), Longing for the House of God, Dwelling in the House of the Ancestors: Local Belief, Christianity and Islam Among the Keo of Central Flores (Fribourg Switzerland: Academic Press, 2004), Wacana Identitas Muslim Pribumi NTT (Editor, 2015, 2018). Sekarang bekerja sebagai Rektor Universitas Katolik Widya Mandira, Kupang, Timor (sejak 2017), Asesor BAN-PT (sejak 2013), dan Anggota Badan Keahlian DPR-RI (sejak 2018). 
Buku ini membahas tentang sejarah masyarakat dan kebudayaan Keo. Beberapa isu utama seperti agama, budaya dan identitas diperbandingkan antara Keo Barat, Keo Tengah, Keo Timur dengan masyarakat suku lainnya. Suatu realitas yang transformatif, dinamis dan kreatif menurut ideologi lokal bersama beberapa unsur seperti ritual, dongeng dan organisasi sosial diulas dari perspektif antropologis berbasis rumah, kampung dan tanah ulayat atau tanah adat.

Gambaran etnografi Keo dan organisasi sosialnya dalam konteks Indonesai Timur yang diulas dengan rujukan pada masyarakat yang berbasis rumah, kampung dan tanah ulayat, kiranya membantu para pembaca untuk dapat memahami masyarakat dan kebudayaan Keo dalam dinamikanya
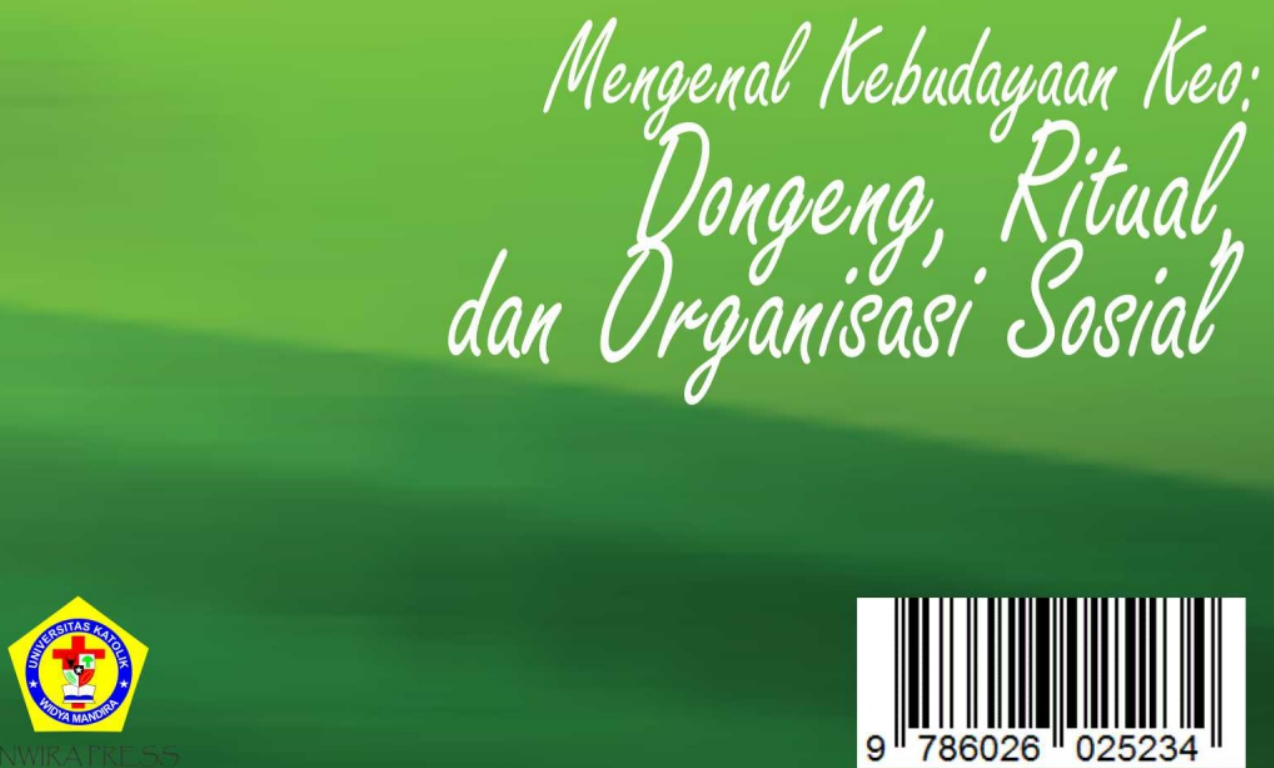